\title{
Mapping user activities and user
} environments during the client intake and examination phase: An exploratory study from the perspective of ankle foot orthosis

\section{users}

\author{
F.C. Holtkamp ${ }^{\mathrm{a}, *}$, M.J. Verkerk ${ }^{\mathrm{b}, \mathrm{c}}$, J. van Hoof ${ }^{\mathrm{a}}$ and E.J.M. Wouters ${ }^{\mathrm{a}}$ \\ anstitute of Allied Health Professions, Fontys University of Applied Sciences, Eindhoven, The Netherlands \\ ${ }^{\mathrm{b}}$ Department of Industrial Engineering and Innovation Sciences, Eindhoven University of Technology, Eindhoven, \\ The Netherlands \\ ${ }^{\mathrm{c}}$ Department of Arts and Social Sciences, Maastricht University, Maastricht, The Netherlands
}

Accepted 6 December 2016

\begin{abstract}
.
BACKGROUND: Non-use of and dissatisfaction with ankle foot orthoses (AFOs) occurs frequently. The objective of this study is to gain insight in the conversation during the intake and examination phase, from the clients' perspective, at two levels: 1) the attention for the activities and the context in which these activities take place, and 2) the quality of the conversation.

METHODOLOGY: Semi-structured interviews were performed with 12 AFO users within a two-week period following intake and examination. In these interviews, and subsequent data analysis, extra attention was paid to the needs and wishes of the user, the desired activities and the environments in which these activities take place.

RESULTS AND CONCLUSION: Activities and environments were seldom inquired about or discussed during the intake and examination phase. Also, activities were not placed in the context of their specific environment. As a result, profundity lacks. Consequently, orthotists based their designs on a 'reduced reality' because important and valuable contextual information that might benefit prescription and design of assistive devices was missed. A model is presented for mapping user activities and user environments in a systematic way. The term 'user practices' is introduced to emphasise the concept of activities within a specific environment.
\end{abstract}

Keywords: Assistive technology, ankle foot orthosis, assessment, environment, user practice, orthopaedic engineering

\section{Introduction}

In the last five years, there were about 50,000 users of orthoses for the lower extremities and approxi-

\footnotetext{
*Corresponding author: Fred Holtkamp, Fontys University of Applied Sciences, Dominee Theodor Fliednerstraat 2, 5631 BN Eindhoven, The Netherlands. Tel.: +31 651942732; E-mail: f.holtkamp@ fontys.nl.
}

mately 104,000 users of orthopaedic shoes in The Netherlands per annum [1]. Although the absolute number of users has remained more or less stable over the last five years, the possibilities for reimbursement for the service of an orthopaedic service supplier have decreased by $17 \%$, though still amounting to as much as $220 \mathrm{M} €$ in 2015 [1]. Reasons for use of these devices vary from congenital malformations to diseases and traumas, such as poliomyelitis, multiple sclerosis, 
cerebrovascular accident, head injuries or club feet, resulting in an aberrant gait pattern [5]. It is expected that in the future a growing number of orthopaedic devices will be needed because of an increase of mobility problems. This will be the result of population ageing, the increasing importance of self-management and independent living, and the desire to participate in society [2-5].

The ankle foot orthosis (AFO) is an orthopaedic device that is able to support the foot and correct gait $[7,8]$. AFOs are available off-the-shelf or custommade. An off-the-shelf AFO is designed to meet a set of requirements and is available in a range of standard sizes and shapes. A custom-made orthosis, which is designed and tailored to the user's specific needs and physiology, can be chosen when the off-the-shelf AFO does not fit correctly or does not meet the specific functional requirements [8].

The International Classification of Functioning, Health and Disability (ICF) and the Process Description of Medical Devices (PDMD) address a multitude of personal and environmental factors $[9,10]$. The ICF and PDMD are used as tools in the prescription, design, manufacturing, delivery and evaluation of AFOs [11,12]. Despite the use of the ICF and the PDMD, users are insufficiently satisfied with their AFOs: studies by van Netten et al. [13] and Holtkamp et al. [6] show that there is a significant level of nonuse of devices and dissatisfaction among people wearing an AFO. Van Netten et al. [14] found percentages of non-use reaching $6 \%$ and dissatisfaction levels reaching a high level of staggering $21 \%$. Holtkamp et al. [6] revealed that $6 \%$ of the users did not use their AFO at all because of dissatisfaction and about $25 \%$ of the users were dissatisfied with their AFO. Moreover, they found that the satisfied and even the very satisfied users, still have serious comments or complaints concerning the quality of the AFO. The majority of these comments concerned the AFO product itself such as the design and functionality, along with many about environmental (home, work, social) and personal factors.

Malkin et al. [15] found that numerous factors affect the perceived usefulness of the AFO: (1) the presence and impact of co-morbidities, (2) the use of painkillers, (3) expectations regarding the advantages in using an AFO and (4) social factors. These social factors include labour-related issues, fashion-related choice of shoes, and the visibility of the AFO, as well as sociopsychological factors related to perceived self-image. Wessel et al. [16] showed that satisfaction is positively influenced by the design of the AFO, or in other words, the look and feel of the product and its aesthetics. The functionality of the AFO, the received care, and the involvement of the AFO user in the design process also influence satisfaction positively [17].

The aforementioned studies clearly show that the entire orthopaedic process requires improvement. In our view, a breakthrough in the quality of assistive devices and user satisfaction can only be realised by taking the perspective of individual users and their specific requirements as a starting point. Starting point for the orthopaedic process is the intake and examination of the client. The objective of this study is to gain insight in the conversation during the intake and examination phase - from the perspective of the client - at two levels, 1) the quality of the conversation, and 2) the attention for the activities and the context in which these activities take place.

\section{Method \\ 2.1. Study design}

This study consists of a qualitative and quantitative part. A qualitative study was conducted consisting of semi-structured interviews based on predefined topics, with AFO users. The interviews were focussed on the experiences and needs of the individual users taking into account the whole orthopaedic chain (Fig. 1). The quantitative part of this study concerns the analysis of the prevalence of the revealed themes representing activities and environments.

\subsection{Participants}

Participants were recruited from two orthopaedic service providers; one located in the centre and one in the northern part of The Netherlands. AFO users were approached by the orthotists of the service provider. Adult male and female AFO users were eligible for, and included in, the study. The assistive device of all participants was prescribed by a physician. Participants were interviewed at a maximum of two weeks after their intake and examination. By this means the chance of loss of recollection with respect to the intake procedure was minimised [18]. Participants were all native speakers of the Dutch language, and received written information of the purpose of the study prior to the interview.

\subsection{Interview scheme and procedure}

Twelve semi-structured interviews were conducted 


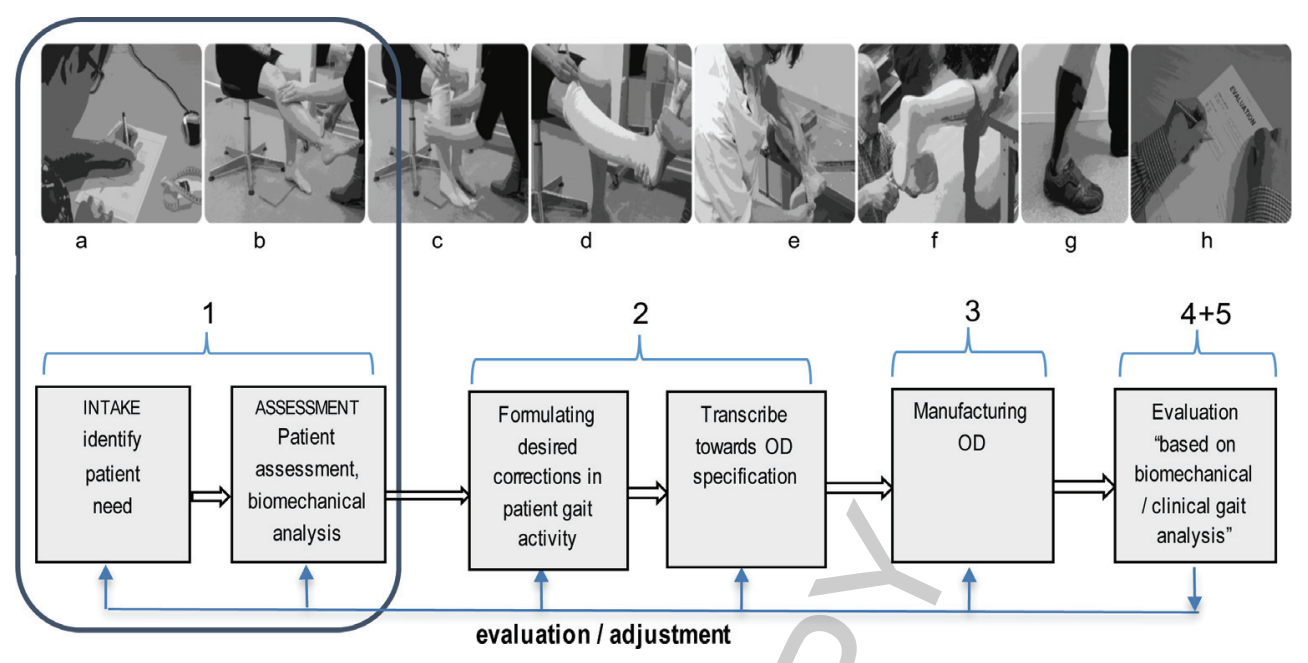

Fig. 1. The entire orthopaedic device process: diagnostics and prescription (data-acquisition), design, manufacturing and tuning/evaluation and delivering. The sub processes are visualised as follows [taken and adapted from Holtkamp et al., 2015]: sub process $1(\mathrm{a}+\mathrm{b})=\mathrm{Intake}$ and examination (diagnostics and prescription); sub process $2(\mathrm{c}+\mathrm{d})=$ Design; sub process $3(\mathrm{e}+\mathrm{f})=$ Manufacturing; sub process $4(\mathrm{~g})=$ Delivering, tuning and maintenance; sub process $5(\mathrm{~h})=$ Evaluation user experience.

by an interviewer and an observer. An advantage of using an interview method compared to a questionnaire is the ability to ask in-depth questions based on the answers given during the interview itself [19]. The role of the interviewer and observer was switched between the two researchers between consecutive interviews. In order to promote the quality of interviews three pilot interviews were conducted. Results of these were transcribed and analysed to tune a topic list and improve the interview technique of the researchers. To obtain insight in the daily life of the participants, the interviewers used a topic list [20] composed of questions concerning general health status, activities in every relevant context (Appendix 1) $[6,21,22]$. In this study, special attention was paid to the activities of the user and the environment in which these activities took place [23]. All the indoor and outdoor activities conducted by the participants in daily life, were asked for.

The structure of each interview was as follows. Each interview was introduced with a word of welcome and an explanation of the purpose of the interview. At first, the user was asked about satisfaction in general and about satisfaction with the AFO in particular. Thereafter, the various activities that filled his or her day were asked for. Subsequently, the researchers systematically explored the activities of the user in relationship to the environment by asking open questions on the personal experiences of the use of the AFO in daily living, and specific questions concerning health and well-being. The user was then asked if, and to what extent, the orthotist had made comparable inquiries about activities and the environment of these activities.
Open questions offered the interviewees an opportunity to share their experiences, to air their opinions, and to make all comments that they deemed necessary [24-26]. The in-depth questions of the researchers were used to clarify given answers and to raise topics that were not addressed. For example, these indepth questions revealed that there are many different types of walking dependent on the specific environment. Each interview ended with an opportunity for the participant to add subjects that had not been discussed with the orthotist or the researchers.

The interviews took 45 to 60 minutes, depending on the number of topics that needed further elaboration. All interviews were recorded with a voice recorder and transcribed verbatim within 48 hours after the interview took place, and were analysed by the researchers. Recording interviews increased confirmability and credibility [25]. The transcripts were sent to the interviewed participant for member check, giving the interviewed participant an opportunity to make adjustments or additions.

\subsection{Data analysis}

The transcribed interviews were analysed through open coding, which yielded relevant fragments of text which were subsequently subjected to axial coding. Finally, after selective coding, themes were defined. The analysis of themes was peer reviewed. In addition, member check was applied in this study [27].

Afterwards, a quantitative analysis was made of the 
Table 1

Characteristics of the participants

\begin{tabular}{|c|c|c|c|c|c|c|c|c|}
\hline Client & $\begin{array}{l}\text { Age } \\
\text { (yrs) }\end{array}$ & $\begin{array}{l}\text { Sex } \\
(\mathrm{m} / \mathrm{f})\end{array}$ & $\begin{array}{l}\text { Marital } \\
\text { status }\end{array}$ & Type of AFO & $\begin{array}{l}\text { Type of } \\
\text { residence }\end{array}$ & $\begin{array}{c}\mathrm{Nr} \text { of } \\
\text { previously } \\
\text { prescribed } \\
\text { AFOs }\end{array}$ & Diagnoses & Indication \\
\hline 1 & 59 & Male & Single & Custom-made & Apartment & 5 & Neurmuscular disorder & Muscle weakness \\
\hline 2 & 83 & Female & Widow & Off-the-shelf & Apartment & 0 & CVA & Drop foot \\
\hline 3 & 74 & Female & Married & Off-the-shelf & Apartment & 1 & Incomplete paraplegia & Loss of muscle control \\
\hline 4 & 71 & Male & Married & Custom-made & Family home & 2 & TIA & Drop foot \\
\hline 5 & 66 & Male & Married & Off-the-shelf & Family home & 3 & CVA & Drop foot \\
\hline 6 & 55 & Female & Single & Off-the-shelf & Family home & 1 & CVA & Drop foot \\
\hline 7 & 69 & Female & Married & Custom-made & Apartment & 2 & CVA & Drop foot \\
\hline 8 & 40 & Female & Married & Custom-made & Family home & 2 & Herniated nucleus pulposus & Nerve damage \\
\hline 9 & 73 & Female & Married & Off-the-shelf & Apartment & 1 & CVA & Drop foot \\
\hline 10 & 45 & Male & $\begin{array}{l}\text { Living } \\
\text { Together }\end{array}$ & Custom-made & Family home & 3 & Herniated nucleus pulposus & Nerve damage \\
\hline 11 & 71 & Male & Single & Custom-made & Apartment & 1 & TIA & Drop foot \\
\hline 12 & 85 & Female & Widow & Custom-made & Family home & 2 & Poly neuropathic disorder & Loss of muscle control \\
\hline
\end{tabular}

CVA $=$ Cerebral Vascular Accident; TIA = Transient Ischemic Attack.

prevalence of the themes representative for the environments and the activities within these environments.

\subsection{Ethics}

The research was conducted within the boundaries set by the Helsinki declaration and approved by the Fontys Committee of Ethics in Research of Fontys University of Applied Sciences, Eindhoven, the Netherlands [28]. Participants were informed by means of an information letter and could withdraw from the study at any moment in time. All participants signed an informed consent document.

\section{Results}

\subsection{Description of the participants}

The mean age of the participants, 5 males and $7 \mathrm{fe}$ males, was 66 years $(\mathrm{SD}=13.8)$. The youngest participant was 40 and the oldest was 85 years of age. Two thirds of the participants already had more than two AFOs prescribed previously in their lifetimes. Participants wearing an AFO as a result of a Cerebral Vascular Accident (CVA) were the most common group of users. The majority of users were active with respect to (voluntary) work, leisure, rehabilitation activities and so on. Each of the users indicated that the AFO was very valuable for their daily life. Without the AFO, many were immobile, as the AFO was the only solution to improve or consolidate gait. Most of the users could hardly walk, ride their bike or drive their car without the use of an AFO. Only one participant made use of the possibility to correct the transcript.

\subsection{User satisfaction}

The users seemed satisfied with their AFO. They were content about the prescription process and the delivered devices. However, a number of participants mentioned that they experienced hindrance from the AFO when going to the bathroom and sitting down. Other users reported that the AFO hindered during driving a car and cycling. In some of the interviews users mentioned the quality of the AFO. For instance, the materials used for the production of the AFO sometimes had sharp edges or irritated the skin.

\subsection{Qualitative analysis}

The qualitative analysis of the interviews revealed two major themes: the main environments in which activities are performed, and the quality of the conversation.

\subsubsection{Activities in environments}

The qualitative analysis showed that users live in four different environments: daily life at home, work, transport, and leisure (Table 2). In general, these different practices were not systematically addressed by the orthopaedic engineer.

The following quotes ${ }^{1}$ illustrate different environments in which a diversity of activities take place:

[P 02] "Yeah, in a small house and we have a very small kitchen, I have to manoeuvre a lot in a small

\footnotetext{
${ }^{1}$ The participant quotes are referred to as [P nr. Participant] and researcher quotes as [R].
} 
Table 2

Description of the four environments

\begin{tabular}{|c|c|}
\hline \multicolumn{2}{|l|}{ Environments } \\
\hline \multicolumn{2}{|l|}{ Daily life in home } \\
\hline Walking indoors & $=$ walking in standard size house on even floor. Small distances and low average speed. \\
\hline Manoeuvring & $=$ move in small indoor areas (kitchen, toilet, bathroom etc.) \\
\hline Walking stairs & $=$ up and down inside the home in using stairs. \\
\hline Housekeeping & $=$ vacuuming, cleaning, window washing, washing clothes \\
\hline \multicolumn{2}{|l|}{ Transport } \\
\hline Walking outdoors & $=$ walking outside on (partly) uneven terrain. Larger distances and higher average speed. \\
\hline Walking & $=$ walking outside the house with low average speed, in terms of shopping etc. \\
\hline Cycling & $=$ recreational \\
\hline Cycling & $=$ commuting - getting daily groceries, etc. \\
\hline Car & $=$ driving by yourself \\
\hline Bus, train, plane & $=$ public transportation \\
\hline \multicolumn{2}{|l|}{ Work } \\
\hline Work professional & $=$ office/desk work, physical work, industry, health care \\
\hline Volunteer work & $\begin{array}{l}=\text { a diversity of activities like hostessing in a long-term care facility, visiting lonely older adults, training the youth of } \\
\text { a sports team, etc. }\end{array}$ \\
\hline Leisure & $=$ shopping, sports, dancing, gardening, social activities, religious activities, etc. \\
\hline
\end{tabular}

place, which demands more attention and concentration and the AFO is hindering me in these movements."

[R] "Can you describe what you are doing during a normal day?"

[P 01] "Sure, in the morning I do some things in the house, like housekeeping, doing groceries and in the afternoon, sometimes voluntary work, not payed of course.

$[R]$ "How do you do your groceries? [P 01] "Well, I do walk to the shops and sometimes I use my bike."

[P 04] "On a winter day these AFOs are so cold that my toes are just freezing. And I work on the land, so that is quite unpleasant."

[P 05] On Tuesdays I'm at the farm; busy planting and sowing seeds.

Table 3 gives an overview of the activities in the different environments for every participant.

\subsubsection{Quality of the conversation}

Our interviews showed that in-depth questions are required to understand the activities of the users in different environments and to cover the whole range of needs and wishes of the user. For example, activities that are not directly related to the daily life at home were generally mentioned only after being asked indepth questions:

$[R]$ "You spoke about your work that you are doing. Does the AFO also support you in the performance of your work?"
[C 01]"Yes, certainly, of course this AFO helps me, although I need to walk the stairs at work rather often. And in walking the stairs the AFO sometimes hurts around my feet."

Specific ambient conditions, such as temperature and humidity, are only revealed by in-depth questions:

[P 04] "On a winter day these AFOs are so cold that my toes are just freezing."

In-depth questions are also necessary to understand the specific nature of an activity. For example, in discussing 'walking' one no further questions were asked with respect to lacing or sports, although the user also engaged in sporting activities.

One user reported that the orthotist was indeed using in-depth questions. An AFO user told that she was ashamed of using the AFO and she had a tendency to hide the AFO. The need to wear an AFO had a big impact on her life and, for this reason, she used to cancel many social activities.

[P 02] "Well this is the worst thing that has happened to me, because I uh... yeah... I always liked my legs, I had nice smooth legs and in a summer day I always walk with bare legs and then uh I really have the feeling that everyone is watching. [...] The orthotist and I have had long discussions about this because I try to avoid the unexpected when I'm somewhere. Just to be sure to avoid uncomfortable situations. The orthotist keeps addressing this by asking questions about the unexpected." 
Table 3

The activities and their environments

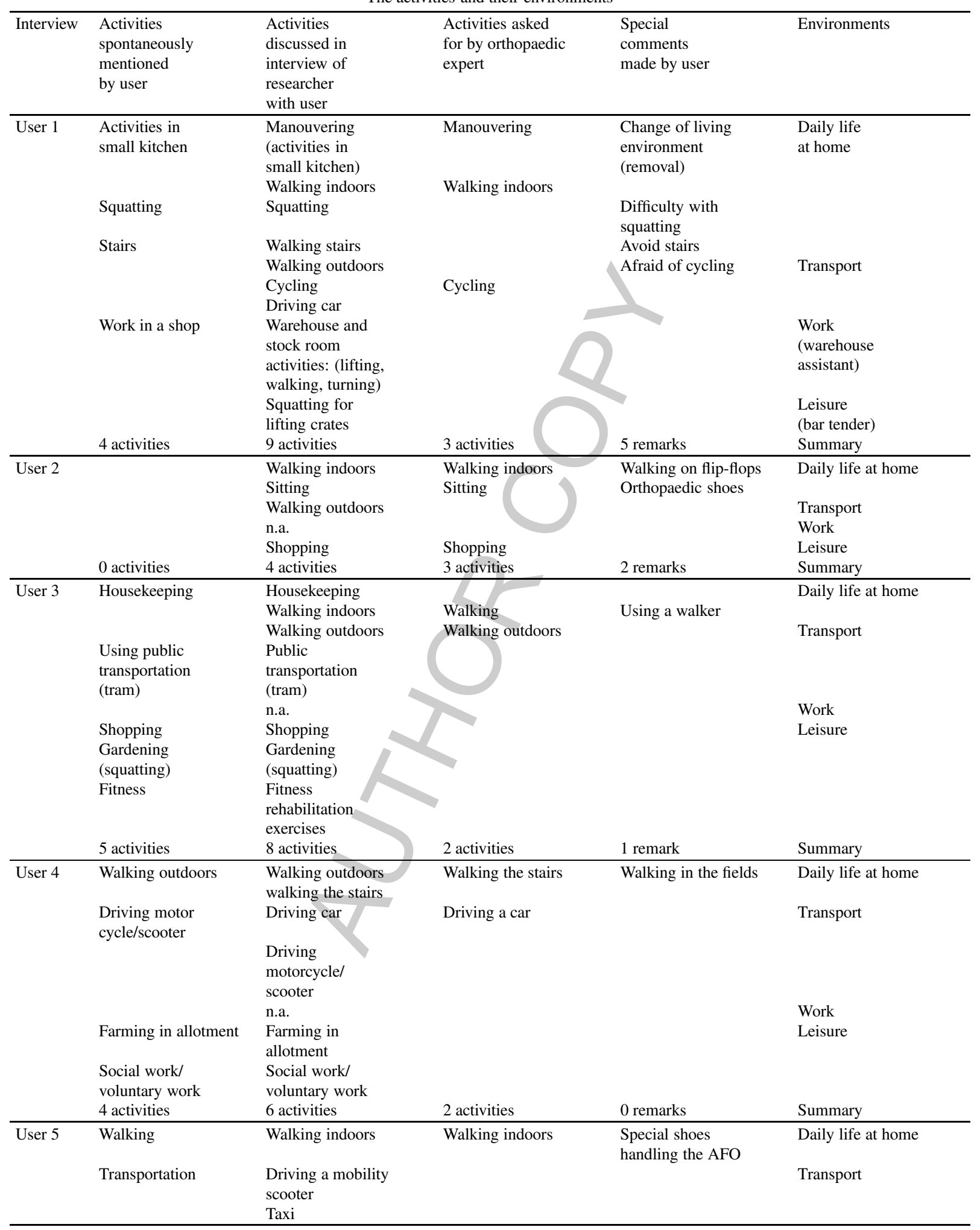


Table 3, continued

\begin{tabular}{|c|c|c|c|c|c|}
\hline Interview & $\begin{array}{l}\text { Activities } \\
\text { spontaneously } \\
\text { mentioned } \\
\text { by user }\end{array}$ & $\begin{array}{l}\text { Activities } \\
\text { discussed in } \\
\text { interview of } \\
\text { researcher } \\
\text { with user }\end{array}$ & $\begin{array}{l}\text { Activities asked } \\
\text { for by orthopaedic } \\
\text { expert }\end{array}$ & $\begin{array}{l}\text { Special } \\
\text { comments } \\
\text { made by user }\end{array}$ & Environments \\
\hline & $\begin{array}{l}\text { Voluntary work } \\
3 \text { activities }\end{array}$ & $\begin{array}{l}\text { Voluntary work } \\
\text { Walking outdoors } \\
\text { Day care } \\
6 \text { activities }\end{array}$ & $\begin{array}{l}\text { Day care } \\
2 \text { activities }\end{array}$ & 2 remarks & $\begin{array}{l}\text { Work } \\
\text { Leisure } \\
\text { Summary }\end{array}$ \\
\hline User 6 & $\begin{array}{l}\text { Driving a scooter } \\
\text { Voluntary work } \\
2 \text { activities }\end{array}$ & $\begin{array}{l}\text { Walking indoors } \\
\text { sitting } \\
\text { Walking outdoors } \\
\text { Driving a scooter } \\
\text { Cycling } \\
\text { Voluntatary work } \\
\text { Swimming } \\
7 \text { activities }\end{array}$ & $\begin{array}{l}\text { Walking indoors } \\
\text { Cycling } \\
\text { Swimming } \\
4 \text { activities }\end{array}$ & 1 remark & $\begin{array}{l}\text { Daily life at home } \\
\text { Transport } \\
\text { Work } \\
\text { Leisure } \\
\text { Summary }\end{array}$ \\
\hline User 7 & $\begin{array}{l}\text { Driving a mobility } \\
\text { scooter } \\
\text { Knitting } \\
\text { Sports } \\
5 \text { activities }\end{array}$ & $\begin{array}{l}\text { Walking indoors } \\
\text { walking the stairs } \\
\text { Standing-kitchen } \\
\text { Sitting } \\
\text { Handling the AFO } \\
\text { Driving a mobility } \\
\text { scooter } \\
\text { n.a. } \\
\text { Knitting } \\
\text { Sports (rehab) } \\
8 \text { activities }\end{array}$ & Walking & Fitting is not correct & $\begin{array}{l}\text { Daily life at home } \\
\text { Transport } \\
\text { Work } \\
\text { Leisure } \\
\text { Summary }\end{array}$ \\
\hline User 8 & $\begin{array}{l}\text { Bathing children } \\
\text { Walking the stairs } \\
\text { Housekeeping } \\
\text { Cycling } \\
\text { Driving a car }\end{array}$ & $\begin{array}{l}\text { Walking } \\
\text { Bathing children } \\
\text { Walking the stairs } \\
\text { Housekeeping } \\
\text { Cycling } \\
\text { Driving a car } \\
\text { Administration } \\
\text { walking } \\
\text { n.a. } \\
7 \text { activities }\end{array}$ & Walking & $\begin{array}{l}\text { Married } \\
\text { two kids } \\
\text { Family house } \\
\text { Shoefitting } \\
\text { Child back of bicycle } \\
\text { Work in hospital - a lot } \\
\text { of walking shoe } \\
\text { information } \\
7 \text { remarks }\end{array}$ & $\begin{array}{l}\text { Daily life at home } \\
\text { Transport } \\
\text { Work }\end{array}$ \\
\hline User 9 & $\begin{array}{l}\text { Social activities } \\
\text { Shopping } \\
\text { Gardening } \\
\text { Visiting theater } \\
6 \text { activities }\end{array}$ & $\begin{array}{l}\text { Housekeeping } \\
\text { walking indoors } \\
\text { Walking the stairs } \\
\text { n.a. } \\
\text { n.a. } \\
\text { Social activies } \\
\text { Shopping } \\
\text { Gardening } \\
\text { Visiting theater } \\
7 \text { activities }\end{array}$ & Walking & 0 remarks & $\begin{array}{l}\text { Transport } \\
\text { Work } \\
\text { Leisure } \\
\\
\text { Summary }\end{array}$ \\
\hline User 10 & $\begin{array}{l}\text { Walking indoors } \\
\text { Bringing kids to } \\
\text { school \& sports }\end{array}$ & $\begin{array}{l}\text { Walking indoors } \\
\text { Bringing kids to } \\
\text { school \& sports } \\
\text { Driving } \\
\text { motorcycle } \\
\text { Office work } \\
\text { Sailing } \\
\text { Tennis } \\
6 \text { activities }\end{array}$ & $\begin{array}{l}\text { Sailing } \\
\text { Tennis } \\
3 \text { activities }\end{array}$ & 0 remarks & $\begin{array}{l}\text { Transport } \\
\text { Work } \\
\text { Leisure } \\
\text { Summary }\end{array}$ \\
\hline
\end{tabular}


Table 3, continued

\begin{tabular}{|c|c|c|c|c|c|}
\hline Interview & $\begin{array}{l}\text { Activities } \\
\text { spontaneously } \\
\text { mentioned } \\
\text { by user }\end{array}$ & $\begin{array}{l}\text { Activities } \\
\text { discussed in } \\
\text { interview of } \\
\text { researcher } \\
\text { with user }\end{array}$ & $\begin{array}{l}\text { Activities asked } \\
\text { for by orthopaedic } \\
\text { expert }\end{array}$ & $\begin{array}{l}\text { Special } \\
\text { comments } \\
\text { made by user }\end{array}$ & Environments \\
\hline \multirow[t]{6}{*}{ User 11} & $\begin{array}{l}\text { Walking indoors } \\
\text { house keeping }\end{array}$ & $\begin{array}{l}\text { Walking indoors } \\
\text { house keeping }\end{array}$ & Walking & $\begin{array}{l}\text { Clinical aspects, } \\
\text { doing on and } \\
\text { off easily }\end{array}$ & Daily life at home \\
\hline & Cycling & Cycling & & & Transport \\
\hline & Public transport & Public transport & & & \\
\hline & & n.a. & & & Work \\
\hline & Shopping & Shopping & & & Leisure \\
\hline & 5 activities & 5 activities & 1 activity & 2 remarks & Summary \\
\hline \multirow[t]{8}{*}{ User 12} & Walking stairs & Walking stairs & Walking & $\begin{array}{l}\text { Caregiver role } \\
\text { important }\end{array}$ & Daily life at home \\
\hline & & Walking & & + & Transport \\
\hline & Driving a car & Driving a car & & & \\
\hline & Cycling & Cycling & & & \\
\hline & & n.a. & & & Work \\
\hline & Social activities & Social activities & & & Leisure \\
\hline & 4 activities & 5 activities & 1 activity & 1 remark & Summary \\
\hline & 29 & 38 & 14 & & $\begin{array}{l}\text { Nr. of distinguished } \\
\text { activities }\end{array}$ \\
\hline
\end{tabular}

Our analysis of the interviews showed that activities of users have to be understood in the specific environments in which they are performed. Only in this way the specific needs and wishes of users can be identified in detail. Our interviews also suggested that probing or in-depth questions are not a standard part of the orthotists' repertoire.

\subsection{Quantitative analysis of activities and environments}

All interviews were quantitatively analysed. In each of the four defined environments a number of activities took place. During the interview, users spontaneously named an average of four activities, with a minimum of zero and a maximum of six. In total 29 different activities were mentioned spontaneously.

By asking in-depth questions, the number of activities reported by the user increased strongly. An average of six and a half activities were mentioned with a minimum of three and a maximum of nine activities. The number of different activities that were distinguished increased to 38 .

In the recollection of users, the orthotist asked an average of two activities with a minimum of one and a maximum of four. In total 14 different activities were identified (Table 3 ).

In Fig. 2 the number of activities of every participant are visualised in a radar chart. The dashed line displays the information the user spontaneously men-

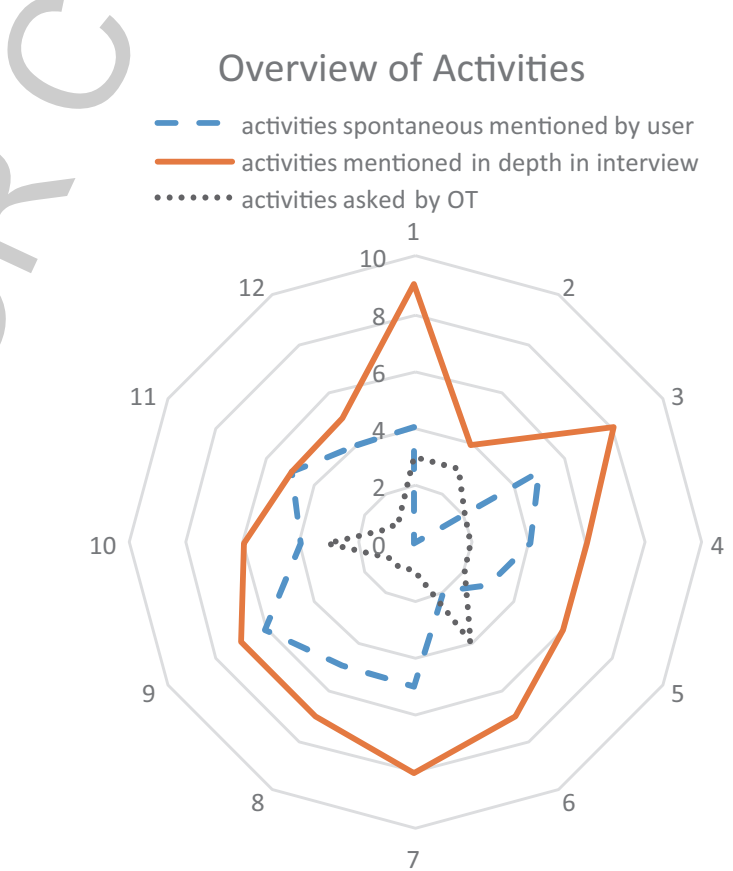

Fig. 2. Overview of activities spontaneously mentioned by the user (the dashed line), identified by the researcher (the continuous line) and discussed with the orthotist (dotted line).

tioned in the interview with the researchers. The outer circle presents the number of activities of the user as revealed by the in-depth interviews. Finally, the inner circle, according to the user's recollection, shows the number activities discussed with the orthotist during the intake and examination phase. Figure 2 shows that 
for all participants (except participant no 11) in-depth questioning is required to make an inventory of all activities. Apparently, participants tell only a part of their activities spontaneously. It shows that for all participants the orthotist raised a limited amount of activities. It also suggests that when the orthotist asked open questions, in most cases (except for participants 1, 2 and 6) more activities would have been identified than by the existing interview technique of the orthotist. The difference between the number of activities identified by the orthotist and by the in-depth analysis of the researchers is large.

In order to verify the conclusions with respect to the quality of the conversation, we asked the participants to what extent probing or in-depth questions during the intake and examination phase were used. A majority of the participants responded that this was not the case. Only two participants reported that walking as an activity was discussed in more depth, followed by an occasional investigation of lacing the shoes when wearing an AFO during sports and motor cycling. The participants confirmed explicitly that a large number of activities were not asked about or discussed during intake and examination. Significant activities that were not touched on by the orthotist included use of public transportation, shopping, performing rehabilitation exercises, working on a farm, and taking care of the children. Participants felt that a number of activities they mentioned spontaneously during intake and examination phase were unnoticed by the orthotist because there was no response on their remarks about moving around in a small kitchen, walking up and down stairs, walking on flip flops, walking outdoors in field, and going to the bathroom.

Table 3 also shows the number of environments spontaneously mentioned by the participant, identified by the researcher in the interview, and 'discussed' with the orthotist. In Fig. 3 these data are visualised in a radar chart. This chart tells roughly the same story as the radar chart of the activities presented in Fig. 2.

Figure 3 shows that for all participants in-depth questioning is required to address all relevant environments. It also shows that the orthotist covered about half of the environments in which users are active, mostly the environments 'daily life at home' and 'transport'. 'Leisure' was seldom a topic of discussion. In none of the cases were all four environments asked for by the orthotist. We asked additional questions to the participants about to what extent the different environments were addressed explicitly by the orthotist. The participants responded that none of the environ-

\section{Overview of Environments;}
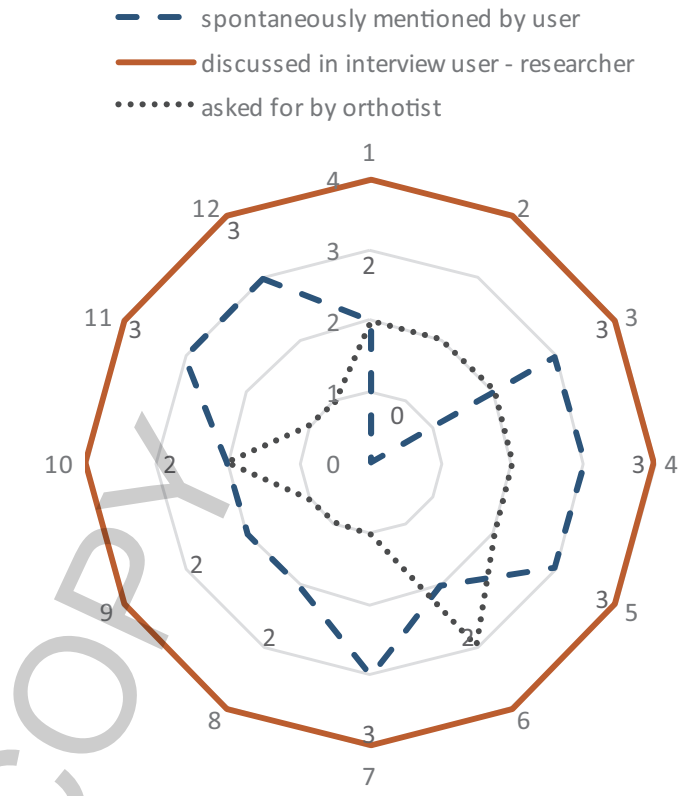

Fig. 3. Overview of environments spontaneously mentioned by the user (dashed line), identified by the researcher (continuous line) and discussed with the orthotist (dotted line).

ments were discussed explicitly during the intake and examination.

During the interviews a total of 22 comments were made. Some comments concerned the AFO itself, others concerned the environment of the user. The importance to map all environments and its activities is illustrated by the following example;

[C 08] "In daily life I have to make use of my bike to bring the children to school! Make sure that I can ride my bike using the AFO. When I came back to collect the splints and mentioned that I would use them on my bike they say that they were not suitable for this."

This user remembered that he mentioned this to the orthotist, but apparently, this was not noticed. In this case no in-depth questions were asked in response to this comments about cycling during the intake and examination phase.

\section{Discussion}

\subsection{Identifying needs of customers}

Recent studies on the satisfaction of AFO users recommended that further research should be focused on 
the perspective and the environment of the user in order to improve the quality of the assistive device and to increase the satisfaction of the users [6,13]. This study investigated the activities of users in detail, as well as the environments in which these activities took place.

All interviews confirmed that relevant information may only be revealed when the interviewer asks indepth questions about the activities in the specific environment in which these activities are performed. Questions about movements like 'turning' or 'stooping' provides no information about the activities per se. But asking about turning and stooping in the kitchen will reveal relevant information. In a small-sized kitchen manoeuvring is more difficult than in a large kitchen which offers more freedom of movement. Also, the movements related to turning and stooping will be quite different for a technician who works in industry. The same reasoning holds for an activity like 'walking'. The specific needs and requirements only come to the fore by asking about the specific environment and its conditions: in home (flat or even underground), in the garden (bumpy underground), at work (temperature, humidity, underground), and leisure (mountain hiking). The same reasoning can be followed in the case of cycling. Cycling in itself tells the expert little about the activity. But analysing cycling in the context of shopping, bringing children to school, or leisure by using in-depth questions, the orthotist should be able to gather important information thoroughly, which helps to shape the design requirements for the AFO.

The interviews provided an insight into the extent the orthotists covered all activities and environments in the intake and examination phase. Our findings show that the orthotists based the design of AFOs on a 'reduced' reality: they identified (only) $30 \%$ of the activities performed by users and discussed (only) $60 \%$ of the environments in which activities are done. That means that not only important activities in the life of users were neglected, but also that important environmental information was unnoticed or overlooked. The use of in-depth questions that cover all environments will improve the quality of information that becomes available for the design process.

Despite an important limitation of this study - the recollection of users - our interviews offered sufficient evidence for our conclusion that orthotists base their designs on a reduced reality. The findings clearly explain why the quality of assistive devices is insufficient and why many users are not satisfied: orthotists do not conduct their interviews in a profound manner with sufficient questions about the activities of users, the environments in which these activities are performed, and conditions of these environments. A more systematically way of questioning the clients will help to increase the quality of the conversation.

These findings are noteworthy. After all, orthotists are familiar with the ICF and PDMD that address key aspects of personal and environmental factors. These approaches are widely used as guidelines and design models in prescribing, designing, manufacturing, delivering and evaluating AFOs. In the ICF, disability and functioning are viewed as outcomes of interactions between health conditions (diseases, disorders and injuries) and contextual factors [9]. The contextual factors cover both external environmental factors (for example, social attitudes, architectural characteristics, legal and social structures, as well as climate, terrain and so forth) and internal personal factors (which include gender, age, coping styles, social background, education, profession, past and current experience, overall behaviour pattern). In the PDMD the activities are defined in the prescribing and choice or design of a medical device. It starts from the moment a problem is reported, defines the design phase and concludes with the evaluation of the medical device and its use that has been supplied. Therefore, the key question is: Why there still remain - despite the use of ICF and PDMD - a substantial level of non-use of devices and a significant level of dissatisfaction among AFO users $[6,14,15,17,29-31]$ ? In our opinion, the answer has to be found in the general character of the ICF and the PMDM that they neither facilitate a systematic and detailed analysis of the activities of users nor support a systematic mapping of the environments in which users are living.

\subsection{The concept of user practices}

At first glance, some activities do not need any explanation. For example, walking was often mentioned during the interviews, which is logical given the fact that an AFO helps to solve a clinical mobility problem. Therefore, walking seems to be well-defined. However, further analysis shows that there are different types of walking, for instance, walking in the home, walking up or down stairs, walking in a small bathroom, walking in the street, walking in the field, walking in the mountains, and so on. Therefore, many different types in walking exist. It is also legitimate to ask whether a user and a clinician have the same understanding of an activity that is called 'walking'. Ideally, inquisitive probing or in-depth questions are asked 
such as: Where do you walk? On what underground do you walk? How do you walk? Do you carry items when you walk? and so on. This type of question helps users to specify important aspects of the activities and the conditions of the environment that are of importance for the design of an AFO.

In our opinion, activities should not be considered separately from the environment in which they take place. Users have a particular role in an environment. The combination of environment and role determines the activities that a user has to do and the accompanying movements that have to be performed. We coined the term 'user practice' to emphasise the idea that activities are performed within an environment that are characteristic for that environment. Firstly, a user practice is about an individual user. Secondly, a user practice is about the practice of an individual user: activities that are repeatedly performed in daily life and habits that constitute daily life. The idea of a user practice is borrowed from a philosophical analysis of professional practices $[25,32]$. A user practice is defined as a coherent set of activities that are performed by users and that are characteristic for the environment in which these activities take place.

This study revealed four general user practices: daily life at home, transport, work, and leisure. Every practice has its own coherent set of activities in a specific environment. 'Daily life at home' consists of activities that are performed in the home of the user like walking indoors, manoeuvring in the kitchen, walking up or down stairs and using the bathroom. Activities in the home have a social character, they serve daily living with other people. Orthotists have to understand the specific home situation of the user, the movements in the home, and the support that the AFO will give to maintain social relationships. 'Transport' is a different set of activities: it is about physical movements that are required to realise social goals (shopping with a partner), economic goals (car driving for a salesman), and juridical goals (walking for a police agent). For every user 'Work' consists of a coherent set of activities too. Generally, the activities and conditions of a work practice are quite different from the practice of 'daily life at home'. The user practice 'work' means that the AFO has to support the different activities in the work situation and has to cope with the specific conditions of the working environment (temperature, humidity, and so on). The final user practice, 'leisure' might consist out of a number of different activities in various environments. For every environment the activities, movements, and conditions have to be analysed. In conclu- sion, an investigation of the different user practices of users provides the orthotist a complete set of information for designing the AFO.

\subsection{Strengths and limitations of this study}

A strength of the study is the diversity of the users: men and women, young and older people, different underlying mobility problems, and the prescription of off-the-shelf and custom-made AFOs.

The interviews gave a detailed insight in the background of the users, the activities they performed and the practices in which these activities were performed. The specific needs and/or conditions in which the AFO needs to be used were made clear. Also, detailed information was given by the interviewees how they experienced the way of working, questioning of the orthotist and how the orthotist dealt with the obtained information.

The quality of the recollection of the participant was a limitation in identifying the activities and practices discussed with the orthotists during intake and examination. However, the interviewer had to ask in-depth questions about the environments to reveal the required details. If the orthotist had also done this, the user would, in all likelihood, remember that. To circumvent this limitation as much as possible, different types of questions were asked to check the given answers.

\section{Conclusions and recommendations}

This study shows that a profound examination is required to identify all activities and all environments in which these activities are performed in order to design an AFO that meets the needs and wishes of customers. During the intake and examination only a limited amount of activities (30\%) and environments in which these activities are performed $(60 \%)$ are addressed. In other words, orthotists base their design on a 'reduced reality'. This leads to a suboptimal prescription and design process of AFOs that, in turn, leads to dissatisfaction among users and non-optimal or nonuse of the assistive device.

The most important recommendation is that orthotists 1) have to map the different environments in which users live, 2) have to analyse the different activities in these environments and the accompanying movements, and 3) have to discuss the specific conditions of these environments. 
In this article, we introduced the idea of a user practice as a coherent set of activities of a user in a specific environment. This user practice model helps to systematically map user activities and environments. This concept seems to be fruitful. Further research is required to confirm the usefulness of this idea. The limitation of this study, that stem from working based on the recollection of participants, could be solved by making real time recordings of the intake and examination phase. This will be part of a follow-up research study.

\section{Acknowledgements}

All participants are thanked for their willingness to share their experiences. Mrs C. Bosman and Mr. M. Ketelaars are thanked for their contributions to this study. Mrs. A. Aprea is thanked for making the photographs. We also thank the users who participated in the interviews Fontys University of Applied Sciences, Eindhoven, the Netherlands, is thanked for providing the financial means to support this study.

\section{Conflict of interest}

None to report.

\section{References}

[1] GIP databank, The drug information system of national health care institute part of Zorginstituut Nederland. 1002-2015. Aantal gebruikers 2009-2013, hulpmiddelencategorie C05: Orthesen. (cited 2016 May 10) URL: http://www. gipdatabank.nl/databank.asp.

[2] Kaljouw M, van Vliet K. Naar nieuwe zorg en zorgberoepen: De contouren. Eds commissie innovatie zorgberoepen en opleidingen. Innovatie Zorgberoepen en Opleidingen, 2015. Zorginstituut Nederland, The Hague, Netherlands.

[3] Huber M, van Vliet M, Giezenberg M, Winkens B, Heerkens, Dagnelie PC, Knottnerus JA. Towards a 'patient-centred' operationalisation of the new dynamic concept of health: A mixed methods study. British Medical Journal Open. 2015. doi: 10.1136/bmjopen-2015-010091.

[4] Huber M, van Vliet M, Boers I. Heroverweeg uw opvatting van het begrip 'gezondheid'. Nederlands Tijdschrift voor Geneeskunde. 2016. 160: A7720.

[5] van Rijn MJ, Schippers EI, (2014) Zorgbelang Nederland. Ministerie van Volksgezondheid, Welzijn en Sport. 2015 (cited 2015-April-12) URL: https://www.rijksoverheid.nl/documenten/rapporten/2014/07/02/de-maatschappij-verandertverandert-de-zorg-mee.

[6] Holtkamp FC, Wouters EJM, van Hoof J, van Zaalen Y, Verkerk MJ. Use of and satisfaction with ankle foot orthoses. Clinical Research on Foot and Ankle. 2015; 3(1): 1000167.
http://dx.doi.org/10.4172/2329-910X.1000167.

[7] Kobayashi T, Leung AKL, Hutchins SW. Techniques to measure rigidity of ankle-foot orthosis: A review. Journal of Rehabilitation Research and Development. 2011; 48, 565-576. doi: 10.1682/JRRD.2010.10.0193.

[8] Bregman DJJ, de Groot V, van Diggele P, Meulman H, Houdijk H, Harlaar J. Polypropylene ankle foot orthoses to overcome drop-foot gait in central neurological patients: A mechanical and functional evaluation. Prosthetics and Orthotics International. 2010; 34(3): 293-304. doi: 10.3109/030 93646.2010.495969.

[9] World Health Organization, International classification of functioning, disability and health. Resolution WHA54.21 of the fifty-fourth World Health Assembly, ninth plenary meeting, agenda item 13.9, 22 May 2001, A54/VR/9. 2001. World Health Organization. Geneva, Switzerland.

[10] Stichting erkenningsregeling leveranciers medische hulpmiddelen (SEMH), Procesbeschrijving hulpmiddelenzorg. 2009; (cited 2015-March 29) URL: http://www.semh.info/CMSDA TA/Afbeeldingen/files/Procesbeschrijving.pdf.

[11] Heerkens YF, Bougie T, de Kleijn-de Vrankrijker MW. Classification and terminology of assistive products. International Encyclopedia of Rehabilitation; ed. Stone JH, The State University of New York; 2011.

[12] Heerkens YF, Bougie T, Claus E. The use of the ICF in the process of supplying assistive products: Discussion paper based on the experience using a general Dutch prescription guideline. Prosthetics Orthotics International. 2014; 35(3) 310-31. doi: 10.1177/0309364611419890.

[13] van Netten JJ, Jannink MJA, Hijmans M, Geertzen JHB, Postema K. Patients' expectations and actual use of custommade orthopaedic shoes. Clinical Rehabilitation. 2010; 10, 919-927. doi: 10.1177/0269215510367991.

[14] van Netten JJ, Jannink MJA, Hijmans JM, Geertzen JHB, Postema K. Use and usability of custom-made orthopedic shoes. Journal of Rehabilitation Research and Development. 2010; 47, 73-82. doi: 10.1682/JRRD.2009.08.0142.

[15] Malkin K, Dawson J, Harris R, Parfett G, Horwood P, Morris C, Lavis G. A year of foot and ankle orthotic provision for adults: Prospective consultations date, with patient satisfaction survey. The Foot. 2008; (18) 75-83. doi: 10.1016/j.foot. 2008.01.001.

[16] Wessels R, Dijcks B, Soede M, Gelderblom GJ, de Witte LP. Non-use of provide assistive technology devices: A literature overview. Disability and Rehabilitation: Assistive Technology. 2003; (15) 231-238.

[17] Bulley C, Shields J, Wilkie K, Salisbury L. User experiences, preferences and choices relating to functional electrical stimulation and ankle foot orthoses for foot-drop after stroke. Physiotherapy. 2011; (97) 226-233.

[18] Postma A, Kessels RPC, van Asselen M. How the brain remembers and forgets where things are: The neurocognition of object - location memory. Neuroscience and Biobehavioral Reviews, 2008; 32(8), 1339-1345. doi: 10.1016/j.neubiorev. 2008.05.001.

[19] Pathak V, Jena B, Kalra S. Qualitative research. Perspectives in clinical research. 2013; 4(3), 192. doi: 10.4103/22293485.115389.

[20] Boeije H. Analyseren in kwalitatief onderzoek, Denken en doen. Boom. Amsterdam, The Netherlands; 2005.

[21] Dijcks BP, de Witte LP, Gelderblom GJ, Wessels RD, Soede M. Non-use of assistive technology in The Netherlands: A non-issue? Disability Rehabiltation: Assistive Technology. 2006; 1(1-2): 97-102. doi: 10.1080/09638280500167548. 
[22] de Boer IG, Peeters AJ, Ronday HK, Mertens BJ, Huizinga TW, Vliet Vlieland TP. Assistive devices: Usage in patients with rheumatoid arthritis. Clinical Rheumatology. 2009; 28(2): 119-128. doi: 10.1007/s10067-008-0989-7.

[23] Verkerk MJ, Hoogland J, van der Stoep J, de Vries M. Philosophy of Technology, An Introduction for technology and business students. Routledge, United Kingdom; 2016.

[24] Opdenakker R. Advantages and disadvantages of four interview techniques in qualitative research, Forum Qualitative Sozialforschung/Forum: Qualitative Social Research 2006; 7(4), Art. 11, http://nbn-resolving.de/urn:nbn:de:0114fqs0604118.

[25] Wouters EJM, van Zaalen-op't Hof Y, Bruijning J. Praktijkgericht onderzoek in de (para) medische zorg, Coutinho, Bussum, The Netherlands; 2015.

[26] Silverman J, Kurtz S, Draper J. Skills for communicating with patients. $3^{\text {rd }}$ edition, CRC Press. Boca Raton, FL, USA, 2013.

[27] Creswell JW. Research Design: Qualitative and quantitative and mixed methods approaches. CA; USA: Sage. 2014; p. 158.

[28] World Medical Association Declaration of Helsinki. Ethical principles for medical research involving human subjects (1964). Adopted by the 18th WMA General Assembly, Helsinki, Finland and last amended by the: 59th WMA General Assembly. Seoul, South Korea: World Medical Association. 2008.

[29] Metcalf C, Adams J, Burridge J, Yule V, Chappell P. A review of clinical upper limb assessments within the framework of the WHO ICF. Musculoskeletal Care. 2007; 5(3): 160-173. doi: http://dx.doi.org/10.1016/j.apmr.2014.02.023.

[30] van Netten JJ, Dijkstra PU, Geertzen JHB, Postema K. What influences a patient's decision to use custom-made orthopaedic shoes? BMC Musculoskeletal Disorders. 2012; (13): 92. doi: 10.1186/1471-2474-13-92.

[31] Arts MLJ, de Haart M, Bus SA, Bakker JPJ, Hacking HGA, Nollet F. Perceived usability and use of custom-made footwear in diabetic patients at high risk for foot ulceration Journal Rehabilitation Medicine. 2014; 46(4): 357-462. doi: 10.2340/16501977-1272.

[32] MacIntyre AC. After Virtue. A Study in Moral Theory, 2nd ed.. London: Duckworth. 1981.

\section{Appendix 1 Interview scheme concerning the prescription procedure of an ankle foot orthosis}

1) Opening statement

- Introduction (goals and aims)

* General Information

* name of the service provider

* AFO prescribed by:

* If applicable, how many AFO were prescribed in past (custom-made/off-the-shelf)?

* First time provision/repetition

2) Opening question:

- How are you doing?

- Can you explain why and where you got this AFO?

Probe-, in-depth questions:
- What were your expectations of the AFO?

- What was discussed in the preliminary stages by the rehabilitation physician, general practitioner and other care professionals concerning the AFO?

- Can you tell more about the referral process?

- What obstacles do you encounter because of your illness/limitations? (social, sports, hobbies, work, home)

- During which activities do you encounter the most obstacles? How can an AFO help?

- Are there situations, where you need help now?

- Is assistance available when needed? If so, from whom? (work, family, friends)

3) Prescription process/user practices/involvement in prescription and design process.

- How did you experience the prescription process?

- To what extent were the following items of your daily life discussed during the prescription process? (Sports/Work/Hobbies/Transportation/Living/Others

- Are there any items/things/activities you wish to do that have not been addressed in the previously discussed aspects?)

To what extent have you been able to think/decide about:

- Design, model, colour, material

- Functions of the AFO

- Personal expectation in what you can do with the AFO.

- Shoe selection

- Do you feel that the discussion of these matters has added value to the AFO delivered?

- To what extent did you feel that all these issues were discussed with your orthopaedic technologist?

- Can you tell us something about how and when to use the AFO? (Is this all clearly explained?)

4) Functioning within the environment

- Can you manage your life and mobility independently or do you have help?

- Family, friends, neighbours, home care

- How does your (this) environment react to the fact that you now have an AFO? (Expectation)

- To what extent do you feel you can use the AFO in the situations described?

- When would you contact the orthotist?

5) Closure. Room for questions, remarks or comments about the interview 